\title{
Çukurova Yöresinde Kırsal Bir Bölgedeki Yetişkinlerin Ruh Sağlığı Durumu ve Etkileyen Faktörler
}

\author{
Psychiatric Health Status and Affecting Factors of Adults in a \\ Rural Area in Çukurova Region \\ Burak Kurt', Muhsin Akbaba²
}

'Kastamonu Merkez Toplum Sağlığı Merkezi

${ }^{2}$ Çukurova Üniversitesi Tıp Fakültesi Halk Sağlığı Anabilim Dalı, Adana

Yazıșma Adresi / Correspondence:

Muhsin Akbaba

Çukurova Üniversitesi Tıp Fakültesi Halk Sağlığı Anabilim Dalı, Adana

T: +903223386060 E-mail: akbaba1953@gmail.com

Geliş Tarihi / Received : 04.06.2018 Kabul Tarihi / Accepted : 09.08.2018

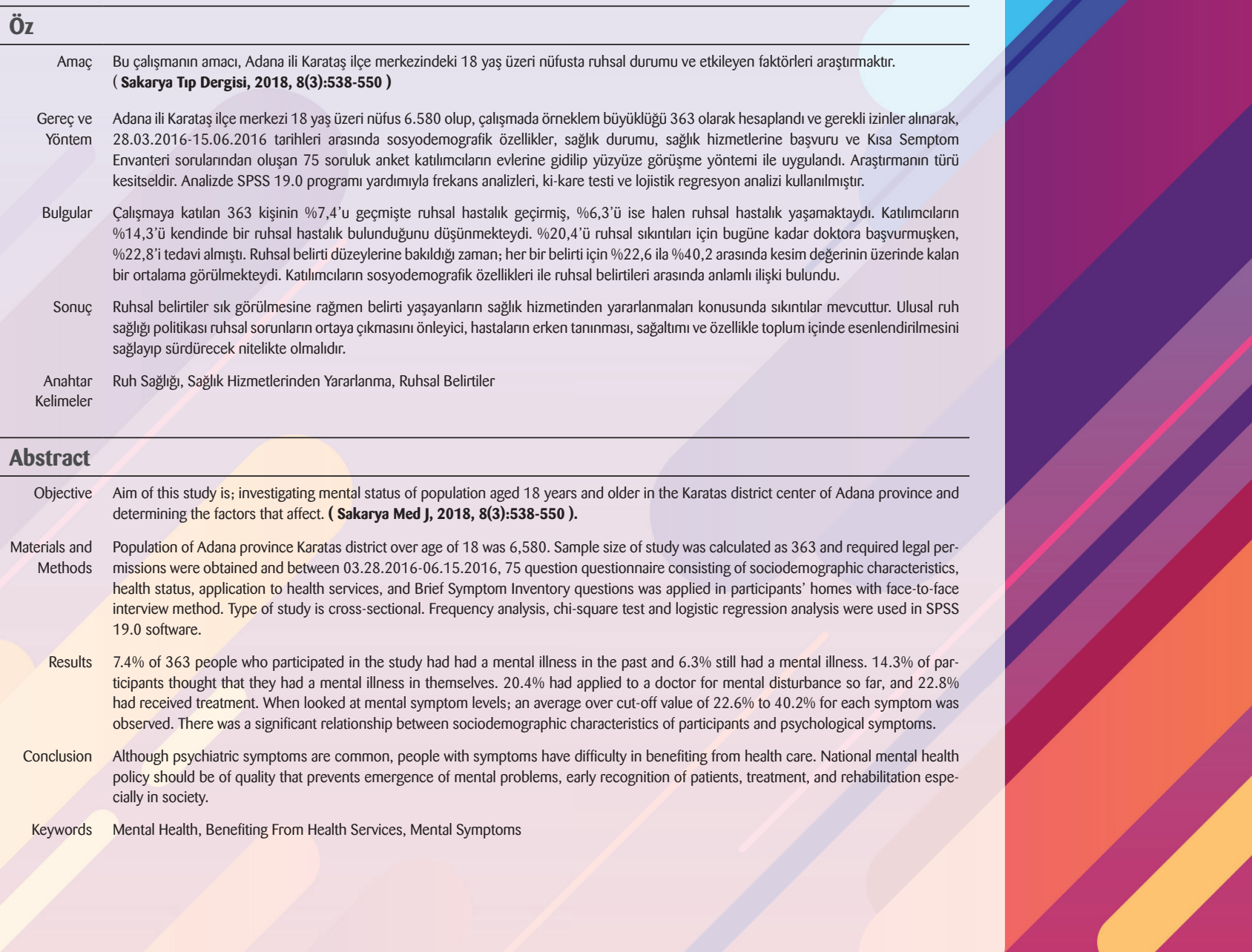


Sakarya TIp Dergisi 2018;8(3):538-550

DSÖ’nün 2014 Ruh Sağlığı Atlası'na göre dünyada her 10 kişiden biri ruh sağlığı sorunu yaşamakta ve yılda 900 bin kişi intihar etmektedir. Gençler arasındaki en yaygın 2. ölüm nedeninin intihar olup, her 4 kişiden biri hayatlarının belli dönemlerinde ruhsal bozukluk geçirmekte ve ruh sağlığı ciddi anlamda bozuk olan her 4 kişiden 3'ünün ise hiçbir tedavi almadığına dikkat çekilmektedir. 2030 yılına kadar depresyonun, getirdiği yük açısından ilk sıraya yerleşeceği ve küresel bir kriz olacağı tahmin edilmektedir. ${ }^{2}$

Günümüzde ruh sağlığı sorunları, belirti ve bozuklukların yaygınlıkları, tıbbi ve toplumsal özellikleriyle ciddi bir halk sağlığı sorunudur. Ülkemizdeki alan araştırmaları, toplum içinde psikiyatrik yardım gerektiren ruhsal sorunların \% 20'nin üzerinde yaygınlığa sahip olduğunu göstermektedir. Ülkemizde en son yapılan yurt geneli çalışma olan ve 1998'de sonuçları yayınlanan, Türkiye'de ruhsal hastalıkların yaygınlığını belirlemek için ülke genelini temsil eden bir örneklemde gerçekleştirilen “Türkiye Ruh Sağlığı Profili” çerçevesinde 18 yaş ve üstündeki 7479 kişiyle görüşülmüştür. Son 12 aydaki tanılar değerlendirildiğinde araştırmaya katılanların \%17,2'sine en az bir ruhsal hastalık tanısı konmuştur. ${ }^{3}$

\section{Bu çalışmanın amacı;}

Adana ili Karataş ilçe merkezindeki 18 yaş üzeri nüfusta ruhsal durumu araştırmak ve etkileyen faktörleri belirlemektir. Toplumda ruhsal bozuklukların yaygınlığı, dağılımı, nedenleri, risk gruplarının saptanması gibi konular koruyucu ruh sağlığı içinde değerlendirilip ülkenin ruh sağlığı politikasının belirlenmesi için gereklidir. Bunları sağlayacak en iyi çalışmalar saha çalışmalarıdır. Kırsal alanda ruhsal belirtilerin yaygınlığının belirlenmesi, olası risk faktörlerinin tanımlanması, ruh sağlığı hizmetlerinden yararlanma durumunun incelenmesi; her türlü eğitim programının hazırlanmasında ve ruh sağlığı hizmetlerinin planlanmasında yol gösterici olacaktır.

\section{Gereç ve Yöntem}

\section{Araştırmanın Tipi}

Bu çalışma Karataş ilçe merkezi içinde 18 yaş üzeri kişilerde ruhsal durum, etkileyen faktörler ve ruh sağlığı hizmetlerinden yararlanma durumunu belirleme amacıyla yapılmış kesitsel tipte bir araştırmadır. Araştırma için Çukurova Üniversitesi Tıp Fakültesi Etik Kurulu’ndan, Adana Halk Sağlığı Müdürlüğü’nden ve Adana Valiliği'nden izin alınmıştır.

\section{Araştırmanın Evreni}

Çalışmanın evrenini Karataş ilçe merkezinde yaşayan 18 yaş üzeri nüfus oluşturmaktadır. 2014 verilerine göre ilçe merkezi 18 yaş üzeri nüfus 6.580'dir.

\section{Örneklem Büyüklüğünün Belirlenmesi Ve Seçimi}


örnek büyüklüğüne ulaşmak için) Güvenilirlik: \%95 Hata payı: \%5 alınmış olup 363 kişiye ulaşmak hedeflendi. Yanıtlamama olasılığı göz önünde bulundurularak \%10 ( $\mathrm{n=36}$ ) yedek denek eklendi. Bu 363 kişiye ulaşmak için sistematik örnekleme yöntemi ile ilçe merkezindeki 1820 haneden 363'ü seçildi. Hane verileri İçişleri Bakanlığı Nüfus ve Vatandaşlık İşleri Genel Müdürlüğü Adres Kayıt Sistemi'nden alındı. Her haneden bir kişi alınmak suretiyle 363 kişiye araştırmacı tarafından yüz yüze anket uygulandı. Yaş dağılımına göre tabakalama yapılmadı. Hanede kapıyı açan ilk kişiye anket formu uygulandı. Kapıyı açan kişinin çalışmaya katılmayı kabul etmediği durumlarda evde ankete katılmayı kabul eden kişiye anket uygulandı. Ankete katılan kişilerden yazılı aydınlatılmış onam formu alındı.

\section{Araştırmanın Uygulanması}

Araştırmaya başlamadan önce aynı bölgede oturan ve örnekleme girmemiş olan 18 yaş üzeri 20 kişi ile görüşülerek ön uygulama yapıldı ve anket formuna son şekli verildi. Daha sonra araştırmaya alınan 363 kişi seçildikten sonra araştırmacı tarafından adresleri bulundu. Görüşmede veri toplanırken her bir kişiye bir anket formu ve kısa semptom envanteri uygulandı. Ortalama haftada 4 gün adresleri belirlenen kişiler araştırmacı tarafından evlerinde ziyaret edilerek yüz yüze görüşmelerle anket formu dolduruldu. Erkek katılımcıların gündüz saatlerinde işte olacağı düşünülerek, ev ziyaretlerinin hafta içi akşam saatlerinde veya hafta sonları yapılmasına özen gösterildi. Katılımcıların kimlik bilgileri toplanmadı. Çalışmanın veri toplama aşaması 28.03.2016-15.06.2016 tarihleri arasında yürütüldü. \%14 oranında red alındı. Red yanıtı vermelerinin sebebi kişisel ve psikolojik bilgilerini paylaşmak istememeleriydi. Çalışmaya katılmayı reddeden kişilerin yerine komşu haneye ziyaret yapıldı. Yedek hanelerle bu açık kapatılarak 363 kişinin tamamına ulaşıldı.

\section{Araştırmada Kullanılan Bağımlı Değişkenler}

Kısa semptom envanteri puanına göre psikiyatrik semptomlar "semptom düzeyi düşük" ve "semptom düzeyi yüksek" şeklinde gruplandırıldı ve bağımlı değişken ikili değişken olarak analiz edildi. Kesim noktası olarak ölçeğin Türkçe uyarlanması çalışmasındaki ortalamalar alındı.

\section{Araştırmada Kullanılan Bağımsız Değişkenler}

- Yaş

- Cinsiyet

- Medeni durum

- Çocuk sayısı

- Kendisinin ve eşinin eğitim durumu

- Kendisinin ve eşinin çalışma durumu

- $\quad$ Ailenin toplam geliri

- Kiminle yaşadığı

- Yaşamının son 5 yılın geçirdiği yer

- Yaşadığı kronik hastalıklar

- Geçmişte ve bugün yaşadığı psikiyatrik hastalıklar

- Kendinde psikiyatrik hastalık olduğunu düşünme durumu

- Akrabalarda psikiyatrik hastalık varlığı

- $\quad$ Ailede bakım gerektiren hasta varlığı

- Doktora başvuru durumu

- $\quad$ Psikiyatrik tedavi alma durumu
Sakarya Tip Dergis

2018;8(3):538-550

AKBABA ve Ark.

Çukurova Yöresinde Kırsal Bir Bölgedeki Yetişkinlerin Ruh Sağlığı Durumu ve Etkileyen Faktörler 


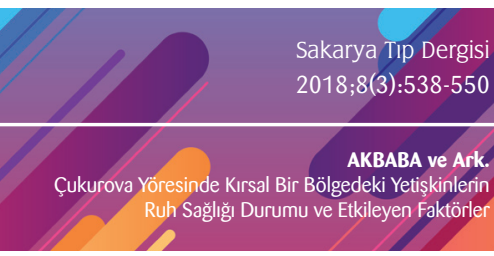

Sakarya IIp Dergis

AKBABA ve Ark

Ruh Sağl|ğı Durumu ve Etkileyen Faktörler

\section{Anket Formu}

Anket formu 75 sorudan ve 3 bölümden oluşmaktadır.

Birinci bölüm: Araştırmaya katılanların yaş, cinsiyet, eğitim durumu, çalışma durumu, ailevi durumu gibi bilgileri kapsayan sosyodemografik özellikleri

İkinci bölüm: Kişinin ve akrabalarının ruhsal hastalık durumu, tanı alma ve tedaviden yararlanma durumları

Üçïncï bölüm: Kısa Semptom Envanteri

\section{Kısa Semptom Envanteri (KSE)}

Kısa Semptom Envanteri (Brief Symptom Inventory) genel bir psikopatoloji değerlendirmesi yapacak kısa ancak geçerli ve güvenilir olan ölçeklere duyulan ihtiyaç üzerine Derogotis (1992) tarafından geliştirilmiş Likert tipi kendini değerlendirme türü bir envanterdir. Kısa Semptom Envanteri, SCL-90-R ile yapılan çalışmalar sonucunda ortaya çıkan SCL-90-R'nin kısa formudur. SCL-90-R'nin dokuz faktörüne dağılmış olan 90 madde arasından, her faktörde en yüksek yükü almış toplam 53 madde seçilmiş ve 5- 10 dakikada uygulanabilen, benzer yapıda kısa bir ölçek elde edilmiştir. Normal örneklemlerde olduğu gibi çeşitli psikiyatrik ve medikal hastalarda ortaya çıkabilecek bazı psikolojik semptomları yakalamak amacı ile geliştirilmiş çok boyutlu bir semptom tarama ölçeğidir. ${ }^{4}$ KSE, 9 alt ölçek, 3 global indeks ve ek maddelerden oluşmaktadır. Ölçeğin ülkemiz için uyarlaması Nesrin Şahin ve Ayşegül Durak tarafından yapılmıştır. ${ }^{5}$ Ölçeğin belirlenen 9 alt ölçeği sırasıyla, somatizasyon (S) $(2,7,23,29,30,33,37$. maddeler), obsesif kompulsif semptom (OKS) $(5,15,26,27,32,36$. maddeler), kişiler arası duyarlılık (KD) $(20,21,22,42$. maddeler), depresyon (D) $(9,16,17,18,35,50$. maddeler), anksiyete $(A)(1,12,19,38,45,49$. maddeler), hostilite $(H)$ $(6,13,40,41,46$. maddeler), fobik anksiyete (FA) $(8,28,31,43,47$. maddeler), paranoid düşünce (PD) $(4,10,24,48,51$. maddeler) ve psikotizm (P) $(3,14,34,44,53$. maddeler) alt ölçekleri olarak oluşturulmuştur. Ek maddeler (EM) ise $(11,25,39,52$. maddeler) yeme içme bozuklukları, uyku bozuklukları, ölüm ve ölüm üzerine düşünceler ve suçluluk duyguları ile ilgili maddeler vardır. KSE, likert tipi bir ölçektir. Her madde "hiç yok / biraz var / orta derecede var / epey var / çok fazla var" seçeneklerine göre cevaplanmakta ve sırasıyla 0, 1, 2, 3, 4 puan verilerek puanlanmaktadır.

\section{Ölçeğin 3 global indeksi şunlardır:}

Rahatsızlık ciddiyeti indeksi (RCi): Alt ölçeklerin toplamının 53'e bölünmesi yoluyla elde edilir: $(\mathrm{S}+\mathrm{OKB}+\mathrm{KD}+\mathrm{D}+\mathrm{A}+\mathrm{H}+\mathrm{FA}+\mathrm{PD}+\mathrm{P}+\mathrm{EM} / \mathrm{53})$

Belirti toplamı (BT): 0 olarak işaretlenen maddeler dışındaki tüm maddelerin (pozitif olan tüm değerler) 1 olarak kabul edilmesi sonucu elde edilen toplam puandır.

Semptom rahatsızlık indeksi (SRi): Alt ölçeklerin toplamının belirti toplamına bölünmesi ile elde edilir: (S+OKB+KD+D+A+H+FA+PD+P+EM / Belirti Puanı)

Ölçekten alınan toplam puanların yüksekliği, bireyin ruhsal belirtilerinin arttığını gösterir. KSE’ndeki her bir ifadenin kendine göre uygunluğunu, beş seçenekten birini seçerek $(0 / 1 / 2$ / 3 / 4) belir- 
ten bireylerin yanıtlarının 9 alt ölçek ve ek maddelerdeki puan ortalamaları değerlendirmeye katlır. Her bireyin ruhsal belirti puan ortalaması, hiç (0 puan), çok az (1 puan), orta derecede (2 puan), oldukça fazla (3 puan), ileri derecede (4 puan) olan puanlara yakınlığı ile değerlendirmeye alınır. Bu puan ortalamaları 4'e yaklaştıkça belirtilerin ileri derecede olduğu, 0'a yaklaştıkça belirtilerin azaldığı görülmektedir. Her alt ölçek, ek madde ve belirti toplamı dışındaki iki global indekste bir birey en fazla 4 puan, en az 0 puan alabilir. Belirti toplamında ise en fazla 53, en az 0 puan alabilir. Ölçek genel ortalama puanı olan RCi'deki artış bireydeki psikiyatrik belirtilerden duyulan sıkıntı artışına işaret eder ve ölçeğin en iyi indeksidir. BT arttıkça, bireyin kendisinde ne kadar çeşitli psikiyatrik belirti algıladığını gösterir. SRi'deki artış ise, bireyin kendisinde var olduğunu algıladığı belirtilerden duyduğu sıkıntının ağılıklı ortalamasını gösterir.

\section{Verilerin Analizi}

Katılımcılara anket uygulanırken soruların çok yanıt seçeneği olan bazı değişkenler istatistiksel analizler için yeniden gruplandııılı (medeni durum, öğrenim durumu, gelir düzeyi, kiminle yaşadığı, son 5 senedir yaşadığı yer). Gelir düzeyi için anketin yapıldığı dönemdeki asgari ücret olan 1000 TL baz alındı.

İstatistiksel analiz olarak verilerin değerlendirilmesinde frekans tabloları, çapraz tablolar, ki-kare testi ve lojistik regresyon analizi yapılmıştır. Önce KSE'deki her bir alt ölçek için ikili değişkenler ile ki-kare analizi yapıımış, burada $p$ değeri 0,1 'in altında bulunan değişkenler tekrar alınarak her bir alt ölçek/indeks için lojistik regresyon analizi yapılmıştr. Sonuçlar ortalamaıstandart sapma veya medyan(min-max), sayı ve yüzde olarak ifade edilmiştir. $p$ değerinin $<0,05$ olduğu durumlar istatistiksel olarak anlamlı kabul edilmiştir.

Bu incelemeler Epi-Info 7 ve SPSS (ver 19.0, Chicago, IL) programı kullanılarak yapılmıştır.

\section{Araştırmanın Bütçesi}

Çukurova Üniversitesi Bilimsel Araştırma Proje Biriminden TTU-2016-5624 no'lu araştırmamıza proje fonu alınmışır. Bu şekilde veri toplama, değerlendirme ve yazım aşamasında kullanılan araç ve gereç temin edilmiştir.

Bulgular

- Katılımcıların \%49,9'u erkek, \%50,1'i kadındı.

- Katılımcıların yaș ortalaması 38,5 513,4 idi.

- Katilımcıların \%78,5’u evli idi. Ortalama çocuk saylları 3,6 $6 \pm 1,2$ idi.

- \%6,3’ü okuryazar değilken, \%7,7'si okuryazar, \%37,5’u ilkokul mezunu, \%24,5’i ortaokul mezunu, \%18,5'i lise mezunu, 20'si $(\% 5,5)$ yüksekokul ve üzeri eğitim seviyesine sahipti. Kadınların eğitim düzeyi erkeklere göre daha düşüktü.

- Katııımcıların \%42,4’ü çalışma hayatındayken, \%57,6'sı çalışmıyordu. Kadınlarda çalışmama oranı $\% 94$ idi.

- Başlıca geçim kaynakları çiftçilik, esnaflık ve balıkçılıktı.

- Aylık hane geliri ortalama 1925 TL idi. Asgari ücretten (1000 TL) daha düşük hane gelirine sahip \%19,8'lik bir kesim vardı.

- Katılımcıların \%35,5'i kronik hastalık sahibiydi.

- Katılımcıların \%7,4'ü geçmişte tanı konulmuş bir psikiyatrik hastalık yaşamıştı. Tanıların \%48,2'si depresyon, \%37,0'ı panik ataktı. Ortalama hastalık yaşama süresi ise 61 aydı.
Sakarya Tıp Dergisi

2018;8(3):538-550

AKBABA ve Ark.

Çukurova Yöresinde Kirsal Bir Bölgedeki Yetişkinlerin Ruh Sağlığı Durumu ve Etkileyen Faktörler 
Sakarya TIp Dergisi 2018;8(3):538-550

- Katılımcıların \%6,3’ü şu anda tanı konulmuş bir psikiyatrik hastalık yaşıyordu. \%34,8'ine depresyon, \%21.7'sine panik atak, yine \%21,7'sine de yaygın anksiyete bozukluğu tanısı konulmuştu. Ortalama hastalık yaşama süresi ise 92 aydı.

- Katılımcıların \%14,3’ü kendisinde psikiyatrik hastalık bulunduğunu düşünüyordu. \%11,3’ünün 1. Derece akrabasında psikiyatrik hastalık mevcuttu.

- Katılımcıların \%20,4'ü ruhsal sıkıntıları için hayatı boyunca en az bir kere doktora başvurmuştu. \%16,5’i geçmişte psikiyatrik tedavi almıştı. \%65’i yalnızca ilaç, \%23,3’ü ilaç+psikoterapi, \%11,7'si ise yalnızca psikoterapi almıştı.

- Katılımcıların \%6,3’ü şu anda psikiyatrik tedavi alıyordu. \%73,9’u yalnızca ilaç, \%21,7’si ilaç+psikoterapi, \%4,4’ü ise yalnızca psikoterapi alıyordu.

\section{Katılımcıların Kısa Semptom Envanteri Değerlendirme Sonuçları}

Katılımcıların Kısa Semptom Envanteri (KSE) ölçeğine göre değerlendirme sonuçları Tablo 1 ve 2'de gösterilmiştir. Kesim değerine göre dağılım yapıldığında, en düşükten en yükseğe göre; katıIımcıların 82'sinde (\%22,6) psikotizm, 100'ünde $(\% 27,5)$ depresyon, 106'sında $(\% 29,2)$ 'sinde ek maddeler, 107'sinde $(\% 29,5)$ hostilite, 109'unda $(\% 30,0)$ semptom rahatsızlık indeksi, 117'sinde $(\% 32,2)$ fobik anksiyete, 122 'sinde $(\% 33,6)$ rahatsızlık ciddiyeti indeksi, 123 'ünde $(\% 33,9)$ belirti toplamı, 124'ünde $(\% 34,2)$ anksiyete, 129'unda $(\% 35,5)$ obsesif-kompulsif semptom, 129'unda $(\% 35,5)$ kişilerarası duyarlılık,140'ında $(\% 38,6)$ paranoid düşünce, 146 'sında $(\% 40,2)$ somatizasyon alt ölçek/indeks puanları kesim değerinin üzerindeydi.

\begin{tabular}{|l|l|l|l|}
\hline \multicolumn{4}{|l|}{ Tablo 1. Katılımcıların KSE Belirtilerinin Tanımlayıcı İstatistikleri } \\
\hline Ruhsal Belirti & Ortalama \pm Standart Sapma & Ortanca & En Düşük-En Yüksek \\
\hline Somatizasyon & $0,55 \pm 0,60$ & 0,29 & $0,00-3,57$ \\
\hline $\begin{array}{l}\text { Obsesif-Kompulsif } \\
\text { Semptom }\end{array}$ & $0,87 \pm 0,66$ & 0,83 & $0,00-3,33$ \\
\hline Kişilerarası Duyarııık & $0,77 \pm 0,75$ & 0,50 & $0,00-3,25$ \\
\hline Depresyon & $0,66 \pm 0,70$ & 0,50 & $0,00-3,67$ \\
\hline Anksiyete & $0,63 \pm 0,63$ & 0,33 & $0,00-2,83$ \\
\hline Hostilite & $0,75 \pm 0,71$ & 0,60 & $0,00-3,40$ \\
\hline Fobik Anksiyete & $0,41 \pm 0,50$ & 0,20 & $0,00-2,60$ \\
\hline Paranoid Düşünce & $1,00 \pm 0,82$ & 0,80 & $0,00-3,40$ \\
\hline Psikotizm & $0,44 \pm 0,53$ & 0,20 & $0,00-3,00$ \\
\hline Ek Maddeler & $0,65 \pm 0,66$ & 0,50 & $0,00-3,00$ \\
\hline $\begin{array}{l}\text { Rahatsızlık Ciddiyeti } \\
\text { Indeksi }\end{array}$ & $0,67 \pm 0,52$ & 0,51 & $0,00-2,68$ \\
\hline Belirti Toplamı & $20,33 \pm 12,81$ & 20,00 & $0,00-53,00$ \\
\hline $\begin{array}{l}\text { Semptom Rahatsızlık } \\
\text { Indeksi }\end{array}$ & $1,54 \pm 0,58$ & 1,50 & $0,00-3,32$ \\
\hline
\end{tabular}




\begin{tabular}{|c|c|c|c|c|c|}
\hline \multirow{2}{*}{ Ruhsal Belirti } & \multirow{2}{*}{ Kesim Değeri } & \multicolumn{2}{|c|}{$\begin{array}{l}\text { Kesim Değerinin } \\
\text { Altında Kalan }\end{array}$} & \multicolumn{2}{|c|}{$\begin{array}{l}\text { Kesim Değerinin } \\
\text { Üzerinde Kalan }\end{array}$} \\
\hline & & Sayı & $\%$ & Sayı & $\%$ \\
\hline Somatizasyon & 0,54 & 217 & 59,8 & 146 & 40,2 \\
\hline Obsesif-Kompulsif Semptom & 1,03 & 234 & 64,5 & 129 & 35,5 \\
\hline Kişilerarası Duyarlılık & 0,86 & 234 & 64,5 & 129 & 35,5 \\
\hline Depresyon & 0,93 & 263 & 72,5 & 100 & 27,5 \\
\hline Anksiyete & 0,79 & 239 & 65,8 & 124 & 34,2 \\
\hline Hostilite & 0,98 & 256 & 70,5 & 107 & 29,5 \\
\hline Fobik Anksiyete & 0,49 & 246 & 67,8 & 117 & 32,2 \\
\hline Paranoid Düşünce & 1,01 & 223 & 61,4 & 140 & 38,6 \\
\hline Psikotizm & 0,72 & 281 & 77,4 & 82 & 22,6 \\
\hline Ek Maddeler & 0,88 & 257 & 70,8 & 106 & 29,2 \\
\hline Rahatsızlık Ciddiyeti İndeksi & 0,82 & 241 & 66,4 & 122 & 33,6 \\
\hline Belirti Toplamı & 25,00 & 240 & 66,1 & 123 & 33,9 \\
\hline Semptom Rahatsızık İndeksi & 1,79 & 254 & 70,0 & 109 & 30,0 \\
\hline
\end{tabular}

\section{Katılımcıların Ruhsal Belirtilerini Etkileyen Bağımsız Değişkenlerin}

\section{Lojistik Regresyon Analiz Sonuçları}

Lojistik Regresyon Analiz Sonuçları Değerlendirildiğinde (Tablo 3):

- Kronik kronik hastalık varlığının ve kendinde psikiyatrik hastalık olduğunu düşünme durumunun Somatizasyon düzeyini anlamlı olarak artırdığı,

- Kendinde psikiyatrik hastalık olduğunu düşünme durumunun Obsesif-Kompulsif Semptom düzeyini anlamlı olarak artırdığı,

- Hiçbir bağımsız değişkenin tek başına Kişilerarası Duyarılık düzeyini anlamlı olarak artırmadığı,

- Eş ile birlikte yaşamamanın ve kendinde psikiyatrik hastalık olduğunu düşünme durumunun Depresyon düzeyini anlamlı olarak artırdığı,

- Kendinde psikiyatrik hastalık olduğunu düşünme durumunun ve doktora başvuru durumunun Anksiyete düzeyini anlamlı olarak artırdığı,

- Kendinde psikiyatrik hastalık olduğunu düşünme durumunun ve doktora başvuru durumunun Hostilite düzeyini anlamlı olarak artırdığı,

- Hiçbir bağımsız değişkenin tek başına Fobik Anksiyete düzeyini anlamlı olarak artırmadığı,

- Birinci derece akrabalarda psikiyatrik hastalık varlığının, kendinde psikiyatrik hastalık olduğunu düşünme durumunun, doktora başvuru durumunun ve Paranoid Düşünce düzeyini anlamlı olarak artırdı̆̆,

- Evli olmamanın, eş ile birlikte yaşamamanın, kendinde psikiyatrik hastalık olduğunu düşünme durumunun ve doktora başvuru durumunun Psikotizm düzeyini anlamlı olarak artırdığı,

- Kadın cinsiyetin, kronik hastalık varlığının ve doktora başvuru durumunun Ek Maddeler düzeyini anlamlı olarak artırdığı,

- Kendinde psikiyatrik hastalık olduğunu düşünme durumunun Rahatsızık Ciddiyeti İndeksi düzeyini anlamlı olarak artırdığı,

- Kendinde psikiyatrik hastalık olduğunu düşünme durumunun Belirti Toplamı düzeyini anlamlı olarak artırdığı,

- 2000 TL ve alı hane gelirinin Semptom Rahatsızlık Indeksin düzeyini anlamlı olarak artırdığı, tespit edilmiştir. 


\begin{tabular}{|c|c|c|c|c|c|c|c|c|c|}
\hline & Kadin cinsiyet & $\begin{array}{l}\text { Hane } \\
\text { geliri } 2000 \mathrm{TL} \\
\text { altunda olmak }\end{array}$ & $\begin{array}{l}\text { Iilkokul ve } \\
\text { altueğtim } \\
\text { düzeyinde } \\
\text { olmak }\end{array}$ & Evli olmamak & $\begin{array}{l}\text { Eş ile birlikte } \\
\text { yaşamamak }\end{array}$ & $\begin{array}{l}\text { Birinci derecee } \\
\text { akrabasinda } \\
\text { rubsal hastalk } \\
\text { bulunmast }\end{array}$ & $\begin{array}{l}\text { Kronik } \\
\text { hastalk sahibi } \\
\text { olmak }\end{array}$ & $\begin{array}{l}\text { Kendinde } \\
\text { psikiyatrik } \\
\text { hastallk } \\
\text { bulunduğunu } \\
\text { düșünmek }\end{array}$ & $\begin{array}{l}\text { Ruhsal sorun } \\
\text { nedeniyle } \\
\text { doktora } \\
\text { bbassururmus } \\
\text { olmak } \\
\text { basvurmuss } \\
\text { olmak }\end{array}$ \\
\hline $\begin{array}{l}\text { Somati- } \\
\text { zasyon }\end{array}$ & - & - & - & - & - & - & $\begin{array}{c}2,97(1,76- \\
5,03)\end{array}$ & $\begin{array}{c}2,96(1,36- \\
6,47)\end{array}$ & - \\
\hline $\begin{array}{l}\text { Obsesif- } \\
\text { Kompulsif } \\
\text { Semptom }\end{array}$ & - & - & - & - & - & - & - & $\begin{array}{c}2,58(1,28- \\
5,19)\end{array}$ & - \\
\hline $\begin{array}{l}\text { Kisilerarası } \\
\text { Duyarlllık }\end{array}$ & - & - & - & - & - & - & - & - & - \\
\hline Depresyon & - & - & - & - & $\begin{array}{c}3,02(1,18- \\
7,71)\end{array}$ & - & - & $\begin{array}{c}3,24(1,56- \\
6,74)\end{array}$ & - \\
\hline Anksiyete & - & - & - & - & - & - & - & $\begin{array}{c}5,02(2,33- \\
10,84)\end{array}$ & $\begin{array}{c}2,62(1,19 \\
5,78)\end{array}$ \\
\hline Hostilite & - & - & - & - & - & - & - & $\begin{array}{c}4,60(2,22- \\
9,54)\end{array}$ & $\begin{array}{c}2,58(1,18- \\
5,61)\end{array}$ \\
\hline $\begin{array}{l}\text { Fobik } \\
\text { Anksiyete }\end{array}$ & - & - & - & & - & - & - & - & \\
\hline $\begin{array}{l}\text { Paranoid } \\
\text { Düşünce }\end{array}$ & - & - & - & - & - & $\begin{array}{c}2,17(1,03- \\
4,58)\end{array}$ & - & $\begin{array}{c}2,96(1,43- \\
6,13)\end{array}$ & $\begin{array}{c}2,17(1,11- \\
4,23)\end{array}$ \\
\hline Psikotizm & - & - & - & $\begin{array}{c}2,92(1,11- \\
7,71)\end{array}$ & $\begin{array}{c}6,23(2,35- \\
16,54)\end{array}$ & - & . & $\begin{array}{c}3,29(1,54- \\
7,00)\end{array}$ & $\begin{array}{c}2,35(1,02- \\
5,38)\end{array}$ \\
\hline $\begin{array}{l}\text { Ek Mad- } \\
\text { deler }\end{array}$ & $\begin{array}{c}1,80(1,06- \\
3,04)\end{array}$ & - & - & - & - & - & $\begin{array}{c}1,90(1,08- \\
3,34)\end{array}$ & . & $\begin{array}{c}3,61(1,53- \\
8,57)\end{array}$ \\
\hline $\begin{array}{l}\text { Rahatsılzlik } \\
\text { Ciddiyeti } \\
\text { İndeksi }\end{array}$ & - & - & - & - & - & - & - & $\begin{array}{c}4,16(1,97- \\
8,78)\end{array}$ & - \\
\hline $\begin{array}{l}\text { Belirti } \\
\text { Toplamı }\end{array}$ & - & - & - & - & - & - & - & $\begin{array}{c}2,90(1,43- \\
5,92)\end{array}$ & - \\
\hline $\begin{array}{l}\text { Semptom } \\
\text { Rahatsszllik } \\
\text { Indeksi }\end{array}$ & - & $\begin{array}{c}2,32(1,31- \\
3,80)\end{array}$ & - & - & - & & & - & - \\
\hline
\end{tabular}

\begin{tabular}{|l|c|c|c|c|c|}
\hline \multicolumn{7}{|l|}{ Tablo 4. Yetişkin Nüfusta Kısa Semptom Envanteri Puan Ortalamaları } \\
\hline Alt Ölçek/ İndeks & ABD & İngiltere & İsrail & $\begin{array}{c}\text { Türkiye/ } \\
\text { Konya }\end{array}$ & $\begin{array}{c}\text { Mevcut } \\
\text { Çalışmamız }\end{array}$ \\
\hline Somatizasyon & $0,29 \pm 0,40$ & $0,43 \pm 0,57$ & $0,62 \pm 0,68$ & $0,5 \pm 0,4$ & $0,55 \pm 0,60$ \\
\hline Obsesif Kompulsif Semptom & $0,43 \pm 0,48$ & $0,59 \pm 0,63$ & $0,94 \pm 0,79$ & $1,0 \pm 0,6$ & $0,87 \pm 0,66$ \\
\hline Kişilerarası Duyarlılık & $0,32 \pm 0,48$ & $0,58 \pm 0,72$ & $0,68 \pm 0,71$ & $0,9 \pm 0,6$ & $0,77 \pm 0,75$ \\
\hline Depresyon & $0,28 \pm 0,46$ & $0,42 \pm 0,65$ & $0,70 \pm 0,69$ & $0,7 \pm 0,5$ & $0,66 \pm 0,70$ \\
\hline Anksiyete & $0,35 \pm 0,45$ & $0,45 \pm 0,60$ & $0,85 \pm 0,71$ & $0,7 \pm 0,5$ & $0,63 \pm 0,63$ \\
\hline Hostilite & $0,35 \pm 0,42$ & $0,44 \pm 0,60$ & $0,72 \pm 0,70$ & $0,9 \pm 0,7$ & $0,75 \pm 0,71$ \\
\hline Fobik Anksiyete & $0,17 \pm 0,36$ & $0,24 \pm 0,50$ & $0,46 \pm 0,61$ & $0,3 \pm 0,4$ & $0,41 \pm 0,50$ \\
\hline Paranoid Düşünce & $0,34 \pm 0,45$ & $0,54 \pm 0,65$ & $0,91 \pm 0,78$ & $0,6 \pm 0,5$ & $1,00 \pm 0,82$ \\
\hline Psikotizm & $0,15 \pm 0,31$ & $0,27 \pm 0,48$ & $0,57 \pm 0,62$ & $0,4 \pm 0,4$ & $0,44 \pm 0,53$ \\
\hline Rahatsızlık Ciddiyeti İndeksi & $0,30 \pm 0,31$ & $0,44 \pm 0,47$ & $0,72 \pm 0,59$ & $0,7 \pm 0,4$ & $0,67 \pm 0,52$ \\
\hline ABD: Amerika Birleşik Devletleri & & & & \\
\hline
\end{tabular}

\section{Tartışma}

\section{Ruhsal Sağlık Sorunlarının Sosyal Belirleyicileri}

Pek çok bulaşıcı olmayan hastalıkta olduğu gibi ruh sağlığı sorunlarının da etyolojisinde genetiğin diğer biyolojik, psikolojik ve sosyal belirleyicilerle etkileşimiyle belirlenen riskler bulunmaktadır. Bir başka anlatımla ruh sağlığı sorunları çok etmenlidir. Ülkeler arasında ve ülke içinde ruh sağlı̆̆ı soru- 
nu prevalansındaki büyük farklılıklar, sosyal belirleyicilerin öne çıktığını göstermektedir.

Ruh sağlığının bu tanımı farklı kültürlerdeki geniş ve çeşitli yorumlamalarla tutarlıdır. Ruh sağlığı sorunu ruhsal/zihinsel bir hastalığın olmamasından çok daha fazlasıdır. Çok geniş kültür ve ülkelerde çalışıldığından, sonuçlar ve elde edilen kanıtlar bireysel, ailesel ve çevresel etmenlerin de rolüne vurgu yaptığından sosyal belirleyiciler gündeme gelmiştir. Güncel literatüre göre bu belirleyiciler:
a) Yaș
b) Cinsiyet
c) Sosyal statü
d) Medeni durum
e) Öğrenim durumu
f) Çalışma durumu/çalışma yaşamı özellikleri
g) Sosyoekonomik durum
h) Ailesel ve çevresel etmenler
i) Yerleşim bölgesi
j) Önemli fiziksel hastalık (kronik hastalık, malignite vb.) durumudur.6

Yaş

Psikolojik sağlık durumu yaşa göre değişmektedir.

Çalışmamıza katılanların \%60,3'ü 40 yaşın altında, \%39,7'si ise 40 ve üzerindeydi. Lojistik regresyon testinde yaş hiçbir alt ölçek/indekste tek başına anlamlı artış sağlamıyordu.

Literatüre göre: Yaş arttıkça ruhsal sorun ve bozuklukların arttığı, 45 yaşın üzerinde nevrozların, 65 yaşın üzerinde ise organik kökenli bozuklukların daha yaygın olduğu görülmüşsür. Yine 40 yaşın üzerinde depresif belirtilerin, depresyonun ve uyku bozukluklarının daha yaygın olduğu görülmektedir. $^{7}$

\section{Cinsiyet}

Lojistik regresyon testinde kadın cinsiyet somatizasyon ve ek maddeler alt ölçeklerinde tek başına anlamlı artış sağlıyordu.

Türkiye Ruh Sağlığı Profili Çalışması'nda ve 2011 yılındaki Türkiye Kronik Hastalıklar ve Risk Faktörleri Sıklığı Çalışması'nda da benzer bulgular vardır. ${ }^{8}$ (Şekil 1)

\section{Sosyal Statü}

Çalışmamıza katılan kadınların eğitim düzeyi erkeklere göre daha düşük bulunmuştur. Kadınlar erken yaşta evlendirilmekte ve genelde evde oturup çocuk büyütmekle zamanlarını geçirmektedir. Erkeklerin \%79'u çalışma hayatındayken, kadınların sadece \%6'sı çalışmaktadır.

Gelişmiş ülkelerdeki çalışmalarda çocuklarına bakmak için evde yalnız oturan kadınlarda, tehlike olarak depresyonun yaygın olduğu bulunmuştur. Toplum taramalarında pek çok tam zamanlı ev hanımı ve bakıı boşluk, mutsuzluk, değersizlik gibi duygular hissettiklerini belirtmiştir. ${ }^{9}, 10$
Sakarya Tip Dergisi

$2018 ; 8(3): 538-550$

AKBABA ve Ark.

Çukurova Yöresinde Kirsal Bir Bölgedeki Yetişkinlerin Ruh Sağıı̆ıı Durumu ve Etkileyen Faktörler 


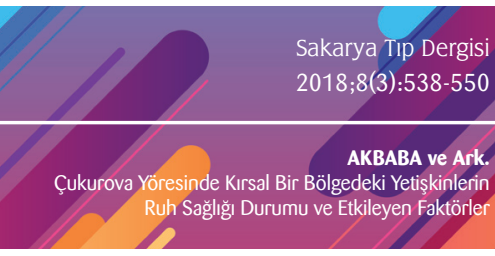

Sakarya TIp Dergis

2018;8(3):538-550

BABA ve Ark.

\section{Medeni Durum}

Çalışmamıza katılanların \%78,5’u evliyken \%21,5'u evli değildi (bekar, boşanmış veya dul). Lojistik regresyon testinde evli olmamak psikotizm alt ölçeğinde tek başına anlamlı artış sağlıyordu.

TÜik Yaşam Memnuniyeti Araştırması, 2014'te evli bireylerin, evli olmayanlara göre daha mutlu olduğu görüldü. Evli bireylerin 2014 yılında \%58,9'u mutlu iken, evli olmayanlarda bu oran \%50 olarak gerçekleşti. ${ }^{11}$

\section{Öğrenim Durumu}

Çalışmamıza katılanların \%51,5’u ilkokul ve daha düşük bir eğitim düzeyine sahipken, \%48,5’i ortaokul ve üstü düzeyde öğrenim görmüştü. Lojistik regresyon testinde ilkokul ve daha düşük düzeyde öğrenim görmek semptom rahatsızlık indeksinde tek başına anlamlı artış sağlıyordu.

Literatüre göre: Genel olarak ruhsal sorunlar öğrenim görmemişlerde daha yüksek prevalansta görülmekle birlikte, bu değişkenin mutlaka yaş, cinsiyet, sosyoekonomik düzey gibi değişkenlere bağlı olduğu gözönünde bulundurulmalıdır. ${ }^{7}$

\section{Çalışma Durumu/Çalışma Yaşamı Özellikleri}

Çalışmamıza katılanların \%42,4'ü aktif olarak çalışmaktayken, \%57,6'sı ise çalışmamaktaydı. Erkeklerde çalışma oranı \%79 seviyesindeyken, kadınlarda bu oran sadece \%6 idi. Katılımcıların eşlerinde de benzer oranlar bulunmuştur. Lojistik regresyon testinde çalışma durumu hiçbir alt ölçek/indekste tek başına anlamlı artış sağlamıyordu.

Literatüre göre: İşsizler istihdam edilenlere göre 2-3 kat daha fazla ruh sağlığı sorunu riskiyle karşı karşıyadır. Artan işsizlik toplumda var olan ruhsal sorunların yaygınlığını ve düzeyini daha da şiddetlendirmektedir. ${ }^{12}$

\section{Sosyoekonomik Durum}

Çalışmamıza katılanların ortalama aylık hane geliri 1925 TL idi. Asgari ücretten (1000 TL) daha düşük ücretle geçinen \%19,8'lik bir kesim bulunuyordu. \%33,3’lük 1001-2000 TL kazanan grubu da eklediğimizde hanelerin yarısından fazlasının geliri 2000 TL’nin altında çıkmaktaydı. Lojistik regresyon testinde hane geliri 2000 TL ve altı olmak semptom rahatsızlık indeksinde tek başına anlamlı artış sağlıyordu.

Literatüre göre: Sosyoekonomik düzeyi daha düşük olan kadınlarda aile içi şiddet daha yaygındır ve eşlerinin alkolü kötüye kullanma oranı daha yüksektir. Dahası bu hassas grupların hizmete erişimi daha az olasıdır. Bu durum ruhsal sorunlara alt yapı hazırlamaktadır. ${ }^{13}$

\section{Ailesel Ve Çevresel Etmenler}

Çalışmamıza katılanların \%11,3’ünün birinci derece akrabasında tanı konulmuş psikiyatrik hastalık mevcuttu. Lojistik regresyon testinde ise ailesinde ruh hastalığı bulunmak paranoid düşünce alt ölçeğinde tek başına anlamlı artış sağlıyordu.

Literatüre göre: Şizofreni için tanımlanan yaşam boyu riskin \%1, şizofrenisi olanların birinci derece akrabalarında \%10, her iki ebeveynde de şizofreni olanlarda \%48 olduğu gösterilmiştir. ${ }^{14,15}$ 


\section{Önemli Fiziksel Hastalık (Kronik Hastalık, Malignite vb.) Durumu}

Çalışmamıza katılanların \%35,5'i kronik hastalık sahibiydi. Lojistik regresyon testinde ise kronik hastalık sahibi olmak somatizasyon ve ek maddeler alt ölçeklerinde tek başına anlamlı artış sağlıyordu.

Literatüre göre; Kalp-damar hastalığı, kanser, diyabet ve solunum sistemi hastalıkları gibi ciddi hastalıklarda psikiyatrik bir komorbidite olarak özellikle depresyon ve anksiyete bozukluklarının yaygın olarak bulunduğu saptanmıştır. ${ }^{16}$

\section{Kısa Semptom Envanteri Puan Ortalamalarının Karşılaştırılması}

Çeşitli çalışmalardan elde edilen yetişkin nüfus KSE puan ortalamaları tablo 4'de verilmiştir. ${ }^{17-20}$

En düşük puan ortalamaları ABD'de görülmektedir. En sık görülen belirtiler obsesif-kompulsif semptom, anksiyete ve hostilitedir. İngiltere, ABD'ye göre daha yüksek belirti ortalamalarına sahiptir. En sık görülen belirtiler ise obsesif-kompulsif semptom, kişilerarası duyarlılık ve paranoid düşüncedir. Ortadoğu ülkelerinden İsrail'de belirti ortalamaları batıya göre yüksektir. En sık görülen belirtiler obsesif-kompulsif semptom, paranoid düşünce ve anksiyetedir. Bu üç çalışma da genel nüfus üzerinde yapılmıştır.

Türkiye'ye bakıldığında ise genel nüfus üzerine KSE uygulaması yapılmış çalışma sayısı sınırıdır. Bu çalışmaların çoğu üniversite öğrencileri gibi sınırlı gruplara yapılmıştır. Son yıllarda kırsal nüfus üzerine yapılmış yegane çalışma olan ve Konya ilinde uygulanan çalışmada ortaya çıkan belirti ortalamaları bizim çalışmamızla uyumludur. Konya çalışmasında en sık görülen belirtiler obsesifkompulsif semptom, kişilerarası duyarlılık ve hostilite olarak bulunmuştur. Bizim çalışmamızda ise paranoid düşünce, obsesif-kompulsif semptom ve hostilite olarak sıralanmıştır.

Doğu toplumlarının belirti ortalamalarının batı toplumlarına göre yüksek olduğu görülmektedir. Girişte de belirttiğimiz gibi ekonomik karmaşalar, toplumsal patlamalar, yerel savaşlar, savaşlara bağı olarak ortaya çıkan büyük göçler, kötü yaşam ve iş koşulları gibi çok sayıda yıkıcı sürecin iç içe işlediği karmaşık ve acı dolu bir tarihsel dönem yaşayan doğu toplumları psikolojik açıdan büyük bir baskı altındadır.

\section{Sonuç ve Öneriler}

Çalışmamızın sonuçlarına göre ruhsal belirtiler her bir semptom için \%30-40 oranında görülmesine ve katılımcların \%14,3'ü kendisinde bir psikiyatrik hastalık olduğunu düşünmesine rağmen sadece \%6,3'ünün psikiyatrik bir tanısı mevcuttu.

Geçmiş hastalıkları da dahil ettiğimizde $\% 20,4^{\prime}$ lük bir doktora başvuru oranı, $\% 22,8^{\prime}$ lik bir tedavi alma oranı ve \%13,7'lik bir tanı oranı mevcuttu.

Doktora başvuru ve tedavi alma oranlarının yüksek olduğu görülmektedir. Bunun son yıllarda artan sağlık hizmetlerine ulaşım kolaylığından kaynaklandığı düşünülmüştür.

Ayrıca doktorun yazmadığı ama oradan buradan edinilen ilaçların da kullanıldığı görülmektedir. Ancak tanı oranının düşüklüğü, hasta-hekim iletişiminin yetersizliğini göstermektedir.
Sakarya Tıp Dergisi

2018;8(3):538-550

AKBABA ve Ark. Çukurova Yöresinde Kırsal Bir Bölgedeki Yetişkinlerin Ruh Sağığı Durumu ve Etkileyen Faktörler 
Hastalar kendilerine verilen tedaviyi uygulamakta ancak bu tedaviyi ne için aldıklarını bilmemektedir. Kendilerine yeterli açıklama yapılmayan hastalar tanılarını bilmemekte ve defalarca farkı sağlık kurumlarına başvurmak ihtiyacı hissetmektedir.

Ülkemizde ruhsal sağlığı geliştirmeyi, hastalıkları önlemeyi, sağalıım, esenlendirme, bakım ve iyileşmeyi kapsayan bütünlüklü ve etkili ruh sağlığı sistemleri tasarlanarak uygulanmalıdır.

Bunun için tüm toplumu kapsayacak geniş saha araştırmalarının yapılmasına ihtiyaç vardır. 
1. Ocaktan ME, Özdemir O, Akdur, R. Birinci Basamakta Ruh Sağığı Hizmet leri. Kriz Dergisi 2004; 12.2:63-73.

2. World Health Organization. Social determinants of mental health. World Health Organization, Geneve, 2004.

3. Akvardar Y. Ruh Sağlğı̆. Ertem M, Çan M (Eds.). Türkiye Sağlık Raporu 2014. Trakya Üniversitesi Matbaası, 2014; 273-288.

4. Derogatis LR. The Brief Symptom Inventory (BSI): Administration, scoring and procedures manual. Minneapolis, MN, National Computer System, 1993.

5. Şahin NH, Durak Battgün A, Uğurtaş S. Kısa Semptom Envanteri (KSE) Ergenler için kullanımının geçerlik, güvenilirlik ve faktör yapısı. Türk Psikiyatri Dergisi, 2002; 13.2:125-135

6. Blas E, Anand SK, eds. Equity, social determinants and public health programmes. World Health Organization, 2010.

7. Güleç C. Toplum ruh sağığı açısından psikiyatrik epidemiyoloji. Güler C.,Akın L (Eds.) Halk sağlığı temel bilgiler 3. Cilt. Genișletilmis 2. Baskı. Ankara: Hacettepe Üniversitesi Basımevi, 2012; 1822-1838.

8. TC Sağlık Bakanlığı Türkiye Halk Sağlığı Kurumu. Türkiye Kronik Hastalıklar ve Risk Faktörleri Sıklı̆ı Calışması, Ankara, 2013.

9. Adak N. Kadın ve sağlık. Sağlık ve Toplum Dergisi 2002; 12.3:15-21.

10. Sadıkoğlu G. (2006) Aile Hekimliğinde kadınların ruh sağı̆ı̆ı. Bilgel N (Ed.). Aile Hekimliği. Bursa: Medikal Tip Kitapevi, 571-81.

11. Türkiye İstatistik Kurumu. TUiK Haber Bülteni, Yaşam Memnuniyeti Araştır ması, 2014. Erişim: (www.tuik.gov.tr/PreHaberBultenleri.do?id=18629). Erişim Tarihi: 17.10 .2017
12. Organisation for Economic Co-operation and Development. Sick on the job?: myths and realities about mental health and work. OECD Publishing, Paris, 2012.

13. Heise L, Ellsberg M, Gottmoeller M. A global overview of gender-based violence. International Journal of Gynaecology and Obstetrics, 2002; 78.S1:5-14

14. Herken H, Ceylan ME. (2009) Genetik. Ceylan ME, Çetin M (Eds.). Şizofreni. ístanbul: İncekara, 319-353.

15. Gümüs D, Herken H. (2007) Sizofreni Genetiği. Soygür H, Alptekin K, Atbaşoğlu EC, Herken H (Eds.). Şizofreni ve Diğer Psikotik Bozukluklar. Ankara: Tuna, 53-71

16. Kayhan F. Bir üniversite hastanesinde yatarak tedavi gören hastalarda depresyon ve anksiyete bozukluklarının yaygınlığı. Uzmanlık Tezi, Selçuk Üniversitesi Meram Tıp Fakültesi Psikiyatri Anabilim Dalı, Konya, 2011.

17. Derogatis, LR, Melisaratos N. The Brief Symptom Inventory: An introductory report. Psychological Medicine, 1983; 13,595-605.

18. Francis, VM, Rajan, P, Turner, N. British community norms for the Brief Symptom Inventory. British Journal of Clinical Psychology, 1990; $29,115-116$.

19. Gilbar O, Ben-zur H. Adult Israeli community norms for the brief symptom inventory (BSI). International Journal of Stress Management, 2002; 9.1:1-10.

20. Dığrak E, Koçoglu D, Akın B. Kırsal Bir Bölgedeki Yetişkinlerde Ruhsal Sorunların Belirlenmesi. Journal of Psychiatric Nursing, 2014; 5.3:122-128.
Sakarya Tıp Dergisi

2018;8(3):538-550

AKBABA ve Ark

Çukurova Yöresinde Kirsal Bir Bölgedeki Yetişkinlerin

Ruh Sağlğı Durumu ve Etkileyen Faktörler 